\title{
The effect of omega-3 fatty acids prescription on serum levels of IL- 6 and IL-1 $\beta$ in patients with traumatic brain injury
}

\author{
Wptyw stosowania kwasu omega-3 na poziom IL-6 i IL-1 $\beta$ w surowicy \\ po obrażeniach mózgu
}

\author{
Farhad Soltani ${ }^{1}$, Mahbobe Rashidi², Reza Akhondzadeh², Mohsen Savaie², Fereshteh Amiri ${ }^{3}$ \\ 1Department of Anaesthesiology and Critical Care, School of Medicine, Ahvaz Jundishapur University of Medical Sciences, Ahvaz, Iran \\ 2Department of Anaesthesiology, Pain Research Centre, Ahvaz Jundishapur University of Medical Sciences, Ahvaz, Iran \\ ${ }^{3}$ Student Research Committee, Ahvaz Jundishapur University of Medical Sciences, Ahvaz, Iran
}

Key words: traumatic brain injury, omega-3, interlukin-1 $\beta$, interlukin-6.

Słowa kluczowe: obrażenia mózgu, kwas omega-3, interleukina $1 \beta$, interleukina 6.

\begin{abstract}
Introduction: Survivors of traumatic brain injury (TBI) continue to suffer from long-term disabilities.

Aim: To investigate the effect of omega- 3 on serum levels of interleukin (IL)-1 $\beta$ and IL-6 in patients with traumatic brain injury.

Material and methods: In this double-blind clinical trial study 80 patients with TBI divided into two 40-memebr groups (50 mg/kg oral omega-3 capsule group, and oral placebo capsule group). Patients took these capsules for 7 days, occurrence of leukocytosis and leukopaenia and Glasgow Coma Score (GCS) was measured. Serum levels of IL-1 $\beta$ and IL-6 were measured on day 7 in each of the two groups. The data were analysed using SPSS software version 20.

Results and conclusions: There was no significant difference between basic demographic information such as age $(p=0.86)$, gender ( $p=0.64)$, APACHE II ( $p=0.16)$, and start of GCS $(p=0.36)$ in the two groups. On the seventh day, the mean GCS was 8.90 \pm 2.03 in the control group and $9.92 \pm 2.69$ in the case group $(p=0.05)$, and the mean white blood cells (WBC) on the third day $(p=0.22)$ and seventh day ( $p=0.58)$, mean of temperature $(p=0.21)$, without mechanical ventilation day $(p=0.89)$, and length of stay in the intensive care unit (ICU) ( $p=0.27$ ) showed no significant differences between the two groups. The serum level of IL-1 $\beta$ was $1154.94 \pm 234.31$ for the control group and $2133.36 \pm 568.08$ for the case group $(p=0.31)$, but the IL-6 level was $296.02 \pm 137.02$ in the control group and $208.54 \pm 90.61$, in the case group that showed significant differences between them $(p=0.001)$
\end{abstract}

\section{Streszczenie}

Wprowadzenie: Pacjenci po obrażeniach mózgu (TBI) nadal doznają długotrwałej niepełnosprawności.

Cel pracy: Określenie wpływu działania kwasu omega-3 na poziom interleukiny (IL)-1 $\beta$ i IL-6 w surowicy po obrażeniach mózgu.

Materiał i metody: W próbie klinicznej przeprowadzonej metoda podwójnie ślepej próby 80 pacjentów z obrażeniami mózgu podzielono na dwie grupy, po 40 osób każda (grupa, której podawano doustnie kapsułki kwasu omega-3 w dawce $50 \mathrm{mg} / \mathrm{kg}$ m.c., oraz grupa otrzymująca placebo). Pacjenci zażywali kapsułki przez 7 dni. Zaobserwowano wystąpienie leukocytozy i leukopenii oraz dokonano oceny według skali Glasgow. W obu grupach 7. dnia zbadano poziom IL-1 $1 \beta$ iL-6 w surowicy. Dane analizowano przy użyciu oprogramowania SPSS ver. 20.

Wyniki i wnioski: Nie stwierdzono istotnych różnic pomiędzy grupami pod względem danych demograficznych, takich jak wiek $(p=0,86)$, płeć $(p=0,64)$, wynik APACHE II $(p=0,16)$ oraz wynik w skali Glasgow $(p=0,36)$. Średni wynik w skali Glasgow 7. dnia wynosił 8,90 $\pm 2.03 \mathrm{w}$ grupie kontrolnej i 9,92 $\pm 2,69 \mathrm{w}$ grupie badawczej $(p=0,05)$. Średnia liczba białych krwinek (WBC) 3. dnia $(p=0,22)$ oraz 7. dnia $(p=0,58)$, średnia temperatura $(p=0,21)$, liczba dni bez wentylacji mechanicznej $(\mathrm{p}=0,89)$ oraz długość pobytu na OIOM-ie $(p=0,27)$ nie wykazywały istotnych różnic pomiędzy grupami. Poziom IL-1 $\beta \mathrm{w}$ surowicy wynosił $1154,94 \pm 234,31 \mathrm{w}$ grupie kontrolnej i 2133,36 $\pm 568,08 \mathrm{w}$ grupie badawczej $(p=0,31)$, jednak poziom IL-6 w grupie kontrolnej wynosił 296,02 \pm 137 , a w grupie badawczej 208,54 $\pm 90,61$, co nie stanowiło istotnej różnicy $(p=0,001)$. 


\section{Introduction}

Survivors of traumatic brain injury (TBI) continue to suffer from long-term disabilities. Even a mild TBI can leave cognitive deficits, concentration deficits, fatigue, and headache [1]. Despite the advances in preventive tools as well as diagnostic and surgical techniques, the TBI management approaches have undergone no significant changes, and almost no effective pharmacological treatment has been proposed to maintain neural support in targeting secondary injury mechanisms [2]. The main focus in TBI management is monitoring and maintaining intracranial pressure (ICP) and cerebral perfusion pressure (CPP) [3]. Currently, frequent neurological examinations and computed tomography (CT) scan are used for assessment of the changes in ICP. Therefore, the use of biomarkers that demonstrate the degree of certainty in ICP conditions can improve patient management. Biomarkers help the clinicians obtain additional and exclusive information from each patient [4]. Classification of TBI patients by biomarkers coupled with common techniques can be used for specialised treatment of this disease [5]. Prognosis of critical patients is associated with their inflammatory conditions. Inflammation results from several reactions and confrontations between different cell types and chemical mediators [6]. Even in other medical studies and inflammatory research areas, the role of the systemic nature of molecular structure and inflammatory changes is important, and several interleukins and other markers such as C-reactive protein play an important role in the human body [7-9]. From them, The IL-1 cytokine family is recognised as a key mediator of peripheral and central inflammatory responses, a molecule that appears to be associated with acute TBI and is present in localised and diffuse injuries [10]. The IL- 1 family consists of agonists (IL- $1 \alpha$, IL-1 $\beta$ ) and antagonists (IL-1r $\alpha$ ), while agonist IL-18 constitutes other family members [11]. Studies have shown a direct correlational between IL-1 $\beta$ levels and prognosis. Serum levels of IL-1 $\beta$ within the first $6 \mathrm{~h}$ of TBI are correlated with GCS over the next $48 \mathrm{~h}$ [12]. Interleukin 6 plays a role in many physiological and pathophysiological processes, and it regulates inflammation, bone metabolism, haematopoiesis, and neuronal evolution [13]. There is evidence of the beneficial effects of IL-6 expression followed by neuronal damage [14]. The rapid increase in IL-6 expression following injury and its maximum measurable levels over the next few hours has meant that this cytokine has been introduced as a biomarker. The serum concentration of this biomarker is measurable after injury [15]. Interleukin 6 is highly sensitive to TBI and can easily be detected in serum; however, the previous data associated with its prognosis potential and its relation to ICP are incomplete and limited. On the other hand, the anti-inflammatory effect of omega-3 unsaturated fatty acids shows that it may be used as a treatment agent in disorders with an inflammatory component. Changing the fatty acid composition of cells involved in the inflammatory response also affects production of peptide mediators of inflammation such as adhesion molecules and cytokines [16]. Anti-inflammatory effects of omega-3 fatty acids have therapeutic value. Obvious or hidden inflammation is observed in certain human conditions and diseases, including rheumatoid arthritis, diabetes type 1, asthma, obesity, systemic response to surgery and trauma, or in patients with severe and chronic illness. The most common consequences of this phenomenon include the high and unpredictable production of inflammatory mediators, including eicosanoids and cytokines [17]. Cytokines such as IL-1 are potent peptide mediators of immune response. They apply profound cellular effects at molecular concentrations in diverse target tissues, including vascular endothelium, central nervous system (CNS), and immune cells. Their synthesis is pharmacologically suppressed by steroids and other immunosuppressive agents such as cyclosporine A. Previous studies have shown that the synthesis of inflammatory cytokines is inhibited by the increase in the content of omega-3 fatty acids in leukocytes [18]. Studies have shown the effects of omega- 3 administration on the function of inflammatory cells and the production or concentration of inflammatory mediators [19].

\section{Aim of the research}

Due to lack of adequate research in this field, in the present study attempts were made to investigate the effect of omega- 3 on serum levels of IL-1 $\beta$ and IL-6 in patients with traumatic brain injury.

\section{Material and methods}

The present study was a double-blind clinical trial on patients with TBI admitted to the intensive care unit of Ahvaz Golestan Hospital in 2017. After obtaining the approval of the Ethics Committee of Ahvaz Jundishapur University of Medical Sciences, Ahvaz, Iran, and the written, informed consent of the patients' parents, a total of eighty $18-50$-year-old patients with TBI were selected as fulfilling the inclusion criteria. In addition, the exclusion criteria were history of seafood allergy, severe and uncontrollable blood pressure, use of immunosuppressive, use of antiplatelet drugs, liver or kidney disorder, or dangerous arrhythmias. Patients were randomly divided into two 40-memebr groups - recipients of the Oral Omega-3 Capsule produced by Canadian Nutri Century Corporation $(\mathrm{O})$, and oral placebo capsules (P). APACHE II criteria were calculated after $24 \mathrm{~h}$ of ICU admission. The omega-3 (O) group received $50 \mathrm{mg} / \mathrm{kg}$ oral omega- 3 capsules every night; the same capsule was administered to the placebo $(\mathrm{P})$ group. Patients 
took these capsules for seven days, occurrence of leukocytosis (12000 WBC) and leukopaenia $(<4000$ WBC) and GCS (Glasco Coma Score) were measured on days 3 and 7 as a measure of the patient's consciousness [3-15], the duration of admission to the ICU was investigated on the days when a ventilator was not needed. Serum levels of IL-1 $\beta$ and IL- 6 were measured on day 7 in each of the two groups, and these variables were investigated via a questionnaire that was completed by a blind operator.

\section{Statistical analysis}

Finally, mean, standard deviations (in quantitative variables), frequency, and percentages ( $n$ qualitative variables) were used for description of the data. T-test (if necessary, the Mann-Whitney test) and $\chi^{2}$ test were used for univariate data analysis. The data analysis was performed using SPSS software version 20, and the significance level was assumed less than 0.05 .

\section{Results}

Regarding the patients' gender, $40 \%$ were female and $60 \%$ were male. $62.5 \%$ of the patients in the control group and $57.5 \%$ of the patients in the case group were male, and no statistically significant difference was found between the gender of patients in the two groups $(p=0.64)$. The mean age of the control group patients was $33.33 \pm 10.10$ years, and the mean age of the case group was $33.68 \pm 8.49$ years. There was no significant difference between the two groups in terms of age $(p=0.86)$. The APACHE II score within $24 \mathrm{~h}$ of ICU admission was $84.75 \pm 17.23$ for the control group and $79.07 \pm 18.52$ for the case group (there was no statistically significant difference between the two groups, $p=0.16$ ). The level of consciousness obtained from the Glasgow Coma Scale (GCS) showed that at the beginning of the study that the mean GCS was $6.97 \pm 1.47$ in the control group and $6.97 \pm 1.47$ in the case group (no statistically significant difference was found between the two groups ( $p=0.36)$, moreover, on the seventh day, the mean GCS was $8.90 \pm 2.03$ in the control group and $9.92 \pm 2.69$ in the case group, and no statistically significant difference was found between the two groups, while the GCS score was much higher in the case group compared to the control group ( $p$ $=0.05)$. The study of WBC on the third day showed that the mean WBC was $2952.27 \pm 57.8504$ in the control group and $99.3084 \pm 85.9323$ in the case group (no significant difference was found between the two groups, $p=0.22$ ). In addition, on the seventh day the mean WBC was $14668.63 \pm 10416.25$ in the control group and $2859.92 \pm 9102.47$ in the case group, and no statistically significant difference was found between the two groups ( $p=0.58$ ). Investigation of the inflammatory factors showed that the serum level of IL-1 $\beta$ was $1154.94 \pm 234.31$ for the control group patients and
$2133.36 \pm 568.08$ for the case group patients, and there was no significant difference between the two groups in this regard $(p=0.31)$. The IL-6 levels was 296.02 \pm 137.02 in the control group and $208.54 \pm 90.61$ in the case group (significantly lower in the case group compared to the control group, $p=0.001$ ). In addition, the temperature of the patients in the control group was $37.78 \pm 0.94$ while the temperature of the case group patients was $37.53 \pm 0.85$ (no statistically significant difference was found between the two groups, $p=0.21$ ). Also, the number of admissions without mechanical ventilation days was $4.39 \pm 8.70$ in the control group and $8.55 \pm 5.23$ in the case group, which showed no statistically significant difference between the two groups $(p=0.89)$. The length of stay in the ICU was equal to $5.33 \pm 12.37$ for patients in the control group and 11.02 \pm 5.61 in the case group. There was no significant difference between the two groups in this regard ( $p=0.27$ ). Finally, the prevalence of mortality was $23.8 \%$ in the patients, with the control group and case group accounting for $25 \%$ and $22.5 \%$ of the mortalities, respectively. No significant difference was found between the two groups in this regard $(p=0.79)$ (Table 1$)$.

\section{Discussion and conclusions}

The results of this study showed that taking $50 \mathrm{mg} /$ $\mathrm{kg}$ oral omega- 3 capsules per night could significantly reduce the serum level of IL- 6 in patients with traumatic brain injury and thus provide insight into a new and rarely-studied biomarker to provide the basis for increasing facilitation of patient monitoring, and to provide more robust results for the administration of oral omega-3 capsules to patients. Oral omega-3 capsules have already been used and studied for purposes similar to those discussed in the present study, and have been tested on humans and animals in different parts of the world. Regarding animal studies, Chen et al. examined the effect of omega- 3 supplements on microglial inflammation following TBI in mice. They found that omega-3 fatty acid supplements can inhibit TBI-induced microglial activation and the incidence of inflammatory factors (TNF- $\alpha$, IL-1 $\beta$, IL- 6 , and IFN- $\gamma$ ), cerebral oedema reduces cell apoptosis and improves neurological functions after TBI [20]. In the present human study, although IL- $1 \alpha$ did not change significantly, the level of IL-6 significantly decreased, which was consistent with the animal study and the basic hypotheses presented by Chen et al [17]. Zhang et al. investigated the long-term neuroprotective effect of omega-3 supplements against cerebral ischaemia (with consideration of anti-inflammatory function of this supplement) [18]. They monitored female mice with or without an omega-3-enriched diet from the second day of pregnancy until 14 days after childbirth. Seven-day-old newborn mice suffering from hypoxic ischaemia were monitored for 5 weeks. The researchers concluded that omega-3 complement can signifi- 
Table 1. Patients' characteristics and test results

\begin{tabular}{|lccc|}
\hline Variable & \multicolumn{2}{c}{ Groups } & \multirow{2}{*}{$P$-value } \\
\cline { 2 - 3 } Age & Control $(n=40)$ & Case $(n=40)$ & 0.86 \\
GCS: & $33.33 \pm 10.10$ & $33.68 \pm 8.49$ & 0.36 \\
\hline $1^{\text {st }}$ day & & & 0.05 \\
\hline $7^{\text {th }}$ day & $6.97 \pm 1.47$ & $7.25 \pm 1.23$ & 0.22 \\
WBC: & $8.90 \pm 2.03$ & $9.92 \pm 2.69$ & 0.58 \\
\hline $3^{\text {th }}$ day & & & 0.21 \\
\hline $7^{\text {th }}$ day & $8504.57 \pm 2952.27$ & $9323.85 \pm 3084.99$ & 0.27 \\
Temperature & $10416.25 \pm 14668.63$ & $9102.47 \pm 2859.92$ & 0.89 \\
ICU duration & $37.78 \pm 0.94$ & $37.53 \pm 0.85$ & 0.31 \\
Days without ventilator & $12.37 \pm 5.34$ & $11.02 \pm 5.61$ & 0.001 \\
\hline IL-1 $\beta$ & $8.70 \pm 4.39$ & $8.55 \pm 5.23$ & $2133.36 \pm 568.08$ \\
IL-6 & $1154.94 \pm 2340.31$ & $208.54 \pm 90.61$ & \\
\hline
\end{tabular}

cantly reduce brain injury and improve the long-term prognosis up to 5 weeks after hypoxic ischemia [18]. Therefore, they confirmed the effective role of omega-3 supplements on animal samples as well. The effectiveness of omega-3 supplements on inflammatory factors in human patients has also been investigated in many studies. For example, Gallai et al. used omega-3 (w-3PUFAS) unsaturated fatty acid supplements in patients with multiple sclerosis, to investigate their effect on secretion of cytokines by peripheral blood mononuclear cells. They stated that the omega-3 supplements resulted in a marked decrease in levels of IL-1 $\beta$ and TNF- $\alpha$ and a reduction in some of the cytokines involved in the immune response [19].

Although the patients and their population were different from the ones in the present study, omega-3 led to a decrease in inflammatory factors in both studies. Although IL-1 $\beta$ decreased in the aforementioned study, it did not undergo any significant change in the present study. TNF- $\alpha$ was also investigated and significantly reduced in the aforementioned study but was not taken into account in the present study. Contrary to the aforementioned study, in the present study IL- 6 was investigated and significantly decreased. Hosny et al. found that high doses of omega-3 result in reduction of pro-inflammatory marker levels on the seventh treatment day in patients with sepsis. The results showed that the time required for mechanical ventilation and development of SOFA criteria in the group receiving high-dosage omega-3 are significantly lower $(p=0.04)$, and they argued that the short-term administration of high-dose omega-3 is safe and has potential effects on the inflammatory cascade. They also concluded that this factor can play an important role in the treatment of patients with sepsis [20]. In the present study, the serum level of IL-6 was significantly decreased as well; however, contrary to the aforementioned study, the ventilation time did not change significantly in either of the two groups. Considering the different clinical conditions, this finding may be attributed to other confounding variables in both studies.

A review of other studies on similar patients and other diseases showed that omega-3 can reduce inflammatory factors; for example, Wang et al. investigated the effects of omega-3 supplementation on postsurgical inflammatory response. Forty-seven patients with gastric cancer, who underwent radical gastrectomy, were randomly assigned into an experimental group (with omega-3 diet) and control group (without omega-3 diet). The levels of inflammatory factors (CRP, TNF- $\alpha$, IL-1, IL-6, and IL-10) were compared. They found that the pre-inflammatory cytokines clearly decreased in the experimental group and argued that the omega-3 supplement can inhibit the pre-inflammatory factors and enhance the release of inflammation inhibitors thus reducing the incidence of SIRS [21]. Although the research population and the patients differ in two articles, omega- 3 has been able to significantly reduce inflammatory factors in both studies. In general, the present study suggests that oral administration of omega- 3 to patients with traumatic brain injury can lead to a decrease in serum levels of IL-6. However, authors are required to cover more variables as well as other inflammatory and cytokine factors in future studies and to evaluate the effect of different doses of omega- 3 at different time intervals. 


\section{Acknowledgments}

The present research article was extracted from the "Thesis" conducted as a research project funded by Research Deputy of Ahvaz Jundishapur University of Medical Sciences, Ahvaz, Iran.

\section{Conflict of interest}

The authors declare no conflict of interest.

\section{References}

1. Hukkelhoven CW, Steyerberg EW, Rampen AJ, Farace E, Habbema JD, Marshall LF, Murray GD, Maas AI. Patient age outcome following severe traumatic brain injury: an analysis of 5600 patients. J Neurosurg 2003; 99: 666-73.

2. Narayan RK, Kishore PR, Becker DP, Ward JD, Enas GG, Greenberg RP, Domingues Da Silva A, Lipper MH, Choi SC, Mayhall CG, Lutz HA 3rd, Young HF. Intracranial pressure: to monitor or not to monitor? A review of our experience with severe head injury. J Neurosurg 1982; 56: 650-9.

3. Treggiari MM, Schutz N, Yanez ND, Romand JA. Role of intracranial pressure values and patterns in predicting outcome introunatic brain injury: a systematic review. Neurocrit Care 2007; 6: 104-12.

4. Statler KD, Jenkins LW, Dixon CE, Clark RS, Marion DW, Kochanek PM. The simple model versus the super model: translating experimental traumatic brain injury research to the bedside. J Neurotrauma 2001; 18: 1195-206.

5. Seltzer MB, Brooks JA. In the line of fire: traumatic brain injury among Iraq War veterans. AAOHN J 2008; 56: 347-53.

6. Molfino A, Amabile MI, Monti M, Muscaritoli M. Omega-3 polyunsaturated fatty acids in critical illness: anti-inflammatory, proresolving, or both. Oxid Med Cell Longev 2017; 2017: 5987082.

7. Yatsiv I, Morganti-Kossmann MC, Perez D, Dinarello CA, Novick D, Rubinstein M, Otto VI, Rancan M, Kossmann T, Redaelli CA, Trentz O, Shohami E, Stahel PF. Elevated intracranial IL-18 in humans and mice after traumatic brain injury and evidence of neuroprotective effects of IL-18-blinding protein after experiment al closed had injury. J Careb Blood Flow Metab 2002; 22: 971-8.

8. Donatello CA. Immunological and inflammatory functions of the interleukin-1 family. Ann Rev Immunol 2009; 27: 519-50.

9. Taşçi A, Okay O, Gezici AR, Ergün R, Ergüngör F. Prognostic value of interleukin-1beta levels after acute brain injury. Neurol Res 2003; 25: 871-4.

10. Romano M, Sironi M, Toniatti C, Polentarutti N, Fruscella P, Ghezzi P, Faggioni R, Luini W, van Hinsbergh V, Sozzani S, Bussolino F, Poli V, Ciliberto G, Mantovani A. Role of IL-6 and its soluble receptor in induction of chemokine's and leukocyte recruitment. Immunity 1997; 6: 315-52.

11. Penkowa M, Camas J, Haber H. Astrocyte-targeted expression of interleukin- 6 protects the central nervous system during neuroglia degeneration induced by 6 -aminoicotinamide. J Neurosis 2003; 73: 481-96.

12. Maegele M, Sauerland S, Bouillon B, Schäfer U, Trübel H, Riess P, Neugebauer EA. Differential immunoresponses following experimental traumatic brain injury, bone fracture and "two-hit: combined neurotrauma. Inflamm Res 2007; 56: 318-23.
13. Calder PC. Omega-3 fatty acids and inflammatory process. J Nutrients 2010; 2: 355-74.

14. Calder PC, Albers R, Antoine JM, Blum S, Bourdet-Sicard R, Ferns GA, Folkerts G, Friedmann PS, Frost GS, Guarner F, Løvik M, Macfarlane S, Meyer PD, M’Rabet L, Serafini M, van Eden W, van Loo J, Vas Dias W, Vidry S, Winklhofer-Roob BM, Zhao J. Inflammatory disease processes and interaction with nutrition. Br J Nutr 2009; 101 (Suppl S1): S1-45.

15. Elders S. n-3 polyunsaturated fatty acids and human cytokine synthesis. Lipids 1996; 31 Suppl: S239-42.

16. Rees D, Miles EA, Banerjee T, Wells SJ, Roynette CE, Wahle KW, Calder PC. Dose-related effects of eicosapentaenoic acid on innate immune function in healthy humans: a comparison of your and older men. Am J Clin Nutre 2006; 83: 331-42.

17. Chen X, Wu S, Chen C, Xie B, Fang Z, Hu W, Chen J, $\mathrm{Fu} \mathrm{H}$, He H. Omega-3 polyunsaturated fatty acid supplementation the HMG-BJ/TLR $/ \mathrm{NF}_{\mathrm{K}} \mathrm{B}$ Pathway following experimental traumatic brain injury. J Neuroinflamm 2017; $14: 143$.

18. Zhang W, Hu X, Yang W, Gao Y, Chen J. Omega-fatty acid supplementation confers long-term neuroprotection against neonatal hypoxic-ischemic brain injury through anti-inflammatory acti3 polyunsaturated on. Stroke 2010; 41: 2341-7.

19. Gallai V, Sarchielli P, Trequattrini A, Franceschini M, Floridi A, Firenze C, Alberti A, Di Benedetto D, Stragliotto E. Cytokine secretion and elcosanoid production in the periphery blood mononuclear cells of MS patients undergoing dietary supplementation with n-3 polyunsaturated fatty acids. J Neuroimmunol 1995; 56: 143-53.

20. Hosny M, Nahas R, Ali S, Abd Elshafei S, Khaled H. Impact of oral omega-3 fatty acids supplementation in early sepsis on clinical outcome and immunomodulation. Egypt J Crit Care Med 2013; 1: 119-26.

21. Wang D, Zhang H, Zhang Y, Li W, Sun X, Xing Y, Suo J. Effects of omega-3 polyunsaturated fatty acids on postoperative inflammatory reaction and clinical efficacy. Zhonghua Wei Chang Wai Ke Za Zhi 2015; 18: 651-5.

\section{Address for correspondence:}

\section{Fereshteh Amiri}

Student Research Committee

Ahvaz Jundishapur University

of Medical Sciences

Ahvaz, Iran

Phone: +989163117578

E-mail: drmdresearcher@gmail.com 